\title{
Oral manifestations in pediatric HIV infection in developing countries based on published research between 2009-2019
}

\author{
Mario P. Mensana ${ }^{1}$, Alexander P. Nugraha ${ }^{1}$, Diah S. Ernawati ${ }^{2}$ \\ ${ }^{1}$ Faculty of Dental Medicine, Universitas Airlangga, Surabaya, East Java, Indonesia \\ ${ }^{2}$ Department of Oral Medicine, Faculty of Dental Medicine, Universitas Airlangga, Surabaya, East Java, Indonesia
}

\begin{abstract}
Introduction: Despite the slogan "One World, One Hope", which has been declared in 1996 as a symbol of global commitment to fight against human immunodeficiency virus (HIV)/acquired immunodeficiency syndrome (AIDS), the tragedy of HIV epidemic among children continue to expand in developing countries, due to combination of factors including, among others, poor socioeconomic conditions and limited access to health facilities. As a child's immune system is immature, HIV infection often worsens at a more progressive rate and presents with various clinical manifestations in the oral cavity. The aim of this study was to review recent findings on oral manifestations prevalent in pediatric HIV patients confined to developing countries.

Material and methods: Literature search was done in accordance with PRISMA in PubMed databases and included cross-sectional observational research published within the last 10 years (2009-2019) on HIV-infected children living in developing countries, assessing intraoral soft tissue lesions. Data were tabulated and calculated for weighted average prevalence of each specific lesion.

Results: A total of 186 articles related to "HIV", "oral manifestation", and "children" keywords were reviewed, yet only 12 articles were selected based on location and design of study, inclusion criteria, methodology used, parameters studied, and presentation of data. Majority of the studies were conducted in India (5 articles). Candidiasis was the most common oral manifestations found in HIVpositive children, followed by angular cheilitis, ulcer, and hyperpigmentation, with a mean prevalence of $44.2 \%, 27.2 \%, 11.1 \%$, and $6.5 \%$, respectively.

Conclusions: Candidiasis remains to be the most common opportunistic infection found in HIV-positive children.
\end{abstract}

HIV AIDS Rev 2020; 19, 4: 222-226

DOI: https://doi.org/10.5114/hivar.2020.101680

Key words: developing countries, HIV-infected children, oral manifestation.

\section{Introduction}

Human immunodeficiency virus (HIV) is a retrovirus that causes progressive host immune system failure and over time, allows life-threatening opportunistic infections and cancer to develop, a condition called acquired immunodeficiency syndrome (AIDS) [1,2]. Globally, HIV infection has become a major health issue, affecting approximately 36.9 million people worldwide and of these, 18.2 million are women of reproduc-
Article history:
Received: 05.11.2019
International Journal of HIV-Related Problems
Received in revised form: 16.03 .2020
Accepted: 17.03.2020
HIV \& AIDS
Re vi e w
Available online: 10.12.2020

Universitas Airlangga, Jl. Mayjen Prof. Dr. Moestopo No.47,

Pacar Kembang, Tambaksari, Surabaya Ci
Indonesia, e-mail: savitri_glx@yahoo.com 
tive age and 1.8 million are children under 15 years of age [3]. A significant majority reside in developing countries [4].

Despite the slogan "One World, One Hope", which has been declared in 1996 as a symbol of global commitment to fight against HIV/AIDS, the tragedy of the HIV epidemic continue to expand in the developing countries, due to a combination of factors including, among others, poor socioeconomic conditions and limited access to health facilities [4]. Many developing countries, such as Indonesia, do not screen for HIV as a part of its routine antenatal care [5]. Consequently, the transmission of HIV to children, which mostly occurs through vertical transmission from infected mothers through pregnancy, labor, and breastfeeding, becomes more prevalent.

HIV infection in children worsens at a more progressive rate due to their immature immune system. As an infant relies on the maternal immune system during the early days of life, disturbance in a mother's immune system due to HIV infection also negatively affects the immunity of newborn [6]. Within one year, an estimated $26 \%$ postnatally and $52 \%$ perinatally HIVinfected infants die due to complications of the infection [7].

With the declining immunity, a higher frequency of pathogenic microorganisms and normal flora infections may occur, manifesting in the oral cavity. HIV-infected children have a higher prevalence of oral soft tissue lesions compared to the general pediatric population, which varies according to the progression of the disease [8]. The objective of this literature search was to review recent findings on oral manifestations prevalent in pediatric HIV patients confined to developing countries.

\section{Material and methods}

A literature search was done in accordance with the Preferred Reporting Items for Systematic Reviews and Meta Anal- yses (PRISMA) in PubMed databases, using the keywords: "HIV", "children", and "oral manifestation". Included papers were restricted to an observational cross-sectional research, providing data on HIV-infected children living in developing countries published within the last 10 years (2009-2019), which assessed the presence of intraoral soft tissue lesions (Figure 1). Data were gathered and tabulated, followed by the calculation of weighted average prevalence of each lesion.

\section{Results}

A total of 186 articles related to "HIV", "children", and "oral manifestation" keywords were reviewed, yet only 12 articles were selected based on the location and design of the study, inclusion criteria, methodology used, parameters studied, and data presentation. The majority of studies were conducted in India (5 articles) (Table 1). Candidiasis was the most common oral manifestations found in HIV-positive children, followed by angular cheilitis, ulcer, and hyperpigmentation, with a mean prevalence of $44.2 \%, 27.2 \%, 11.1 \%$, and $6.5 \%$ respectively (Table 2).

\section{Discussion}

Between 2009-2019, research on oral manifestations in children with HIV/AIDS living in developing countries are limited, despite its importance in early diagnosis and in monitoring the progression of the infection to AIDS. Although laboratory tests, such as CD4+ lymphocyte count and HIV viral load, are the most accurate markers in determining the course of the infection, these tests are not applicable in many resource-limited settings in developing countries. Inspecting oral lesions, which are present in $70-90 \%$ of HIV-

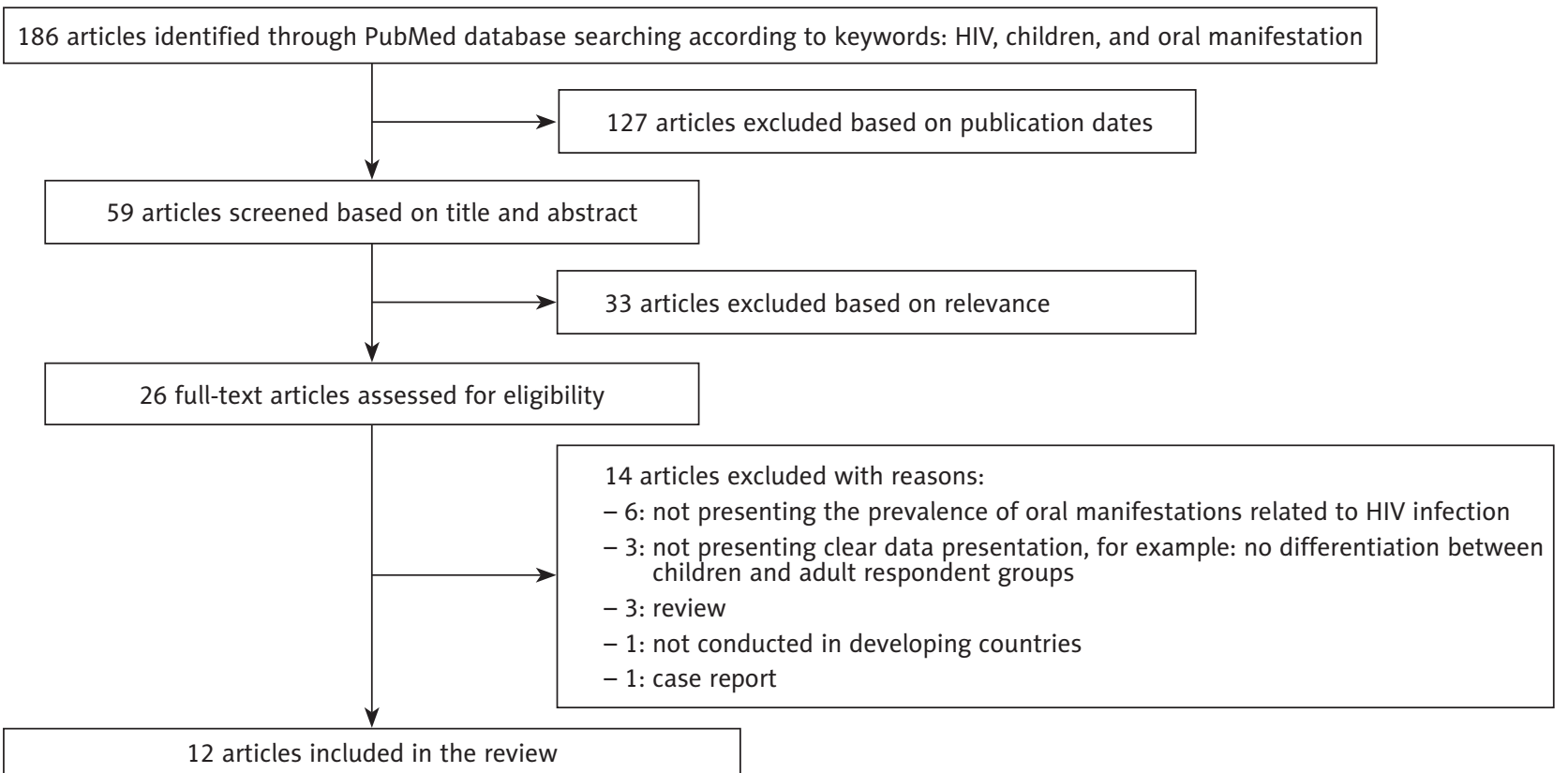

Figure 1. Flow chart 
Table 1. List of published research between 2009-2019 included in the present review, assessing oral manifestations in HIV-infected children

\begin{tabular}{|c|c|c|c|c|}
\hline Authors, year of publication [ref] & No. of HIV-positive children & Age (years) & ART & Country \\
\hline Ranganathan et al., 2010 [9] & 212 & 6 months -14 years & $\begin{array}{c}N-212 \\
Y-0\end{array}$ & India \\
\hline Rwenyonyi et al., 2011 [8] & 237 & $1-12$ years & $\begin{array}{l}Y-118 \\
N-119\end{array}$ & Uganda \\
\hline Davila et al., 2011 [10] & 37 & N.A. $($ mean, $5.13 \pm 3.79)$ & N.A. & Venezuela \\
\hline Ponnam et al., 2012 [11] & 190 & $5-15$ years & $\begin{array}{l}Y-95 \\
N-95\end{array}$ & India \\
\hline Adebola et al., 2012 [12] & 105 & 2-156 months & $\begin{array}{l}Y-65 \\
N-40\end{array}$ & Nigeria \\
\hline Baghirath et al., 2013 [13] & 100 & $5-12$ years & $\begin{array}{l}Y-50 \\
N-50\end{array}$ & India \\
\hline Jose et al., 2013 [14] & 100 & $2-12$ years & $\begin{array}{l}Y-47 \\
N-53 \\
\end{array}$ & India \\
\hline Subramaniam et al., 2015 [15] & 221 & $6-18$ years & $\begin{array}{l}Y-109 \\
N-112\end{array}$ & India \\
\hline Oyedeji et al., 2015 [16] & 58 & 3 months -13 years & $\begin{array}{l}Y-37 \\
N-21\end{array}$ & Nigeria \\
\hline Oliscovicz et al., 2015 [17] & 111 & $2-16$ years & $\begin{array}{l}Y-97 \\
N-14\end{array}$ & Brazil \\
\hline Lugito et al., 2016 [18] & 70 & $1-12$ years & $\begin{array}{c}Y-70 \\
N-0\end{array}$ & Indonesia \\
\hline Mensana et al., 2018 [19-21] & 28 & $1-15$ years & $\begin{array}{l}Y-24 \\
N-4\end{array}$ & Indonesia \\
\hline
\end{tabular}

N.A. - not available, $m$ - months, HAART - anti-retroviral therapy, $Y$-yes, number of children undergoing ART, $N-$ no, number of children not undergoing ART

infected individuals during different stages of the disease, is therefore the simplest, most cost-effective, and non-invasive procedure to perform by clinicians [22].

Since 1993, various oral conditions associated with HIV/ AIDS in children have been described by EC-Clearinghouse. These conditions observed in children are different to adults. HIV-positive children most commonly present with oral candidiasis, which includes angular cheilitis, herpes simplex virus (HSV) infection, linear gingival erythema (LGE), parotid enlargement, and recurrent aphthous ulcers [23]. Findings from the 12-research reviewed in this paper are consistent with the EC-Clearinghouse classification, as candidiasis (44.2\%), angular cheilitis (27.2\%), and ulcers (11.1\%) were still the most common manifestations observed. Oral candidiasis was consistently observed in all 12 research, and angular cheilitis and ulcers were reported in most of the reviewed research, being identified in 9 and 10 research, respectively.

As the EC-Clearinghouse classification was made before the advent of antiretroviral therapy (ART), hyperpigmentation of oral mucosa was not considered common in children. Zidovudine (AZT), one of ARTs commonly provided to HIV-positive children, has been reported to cause oral brownish pigmentation [24]. AZT or its metabolites is assumed to increase melanin production or being accumulated in the mucosa forming complexes with melanin or iron [25].
With the increasing number of children receiving AZT, hyperpigmentation is expected to be more prevalent.

According to the EC-Clearinghouse classification, LGE and HSV infection are also common findings in children with HIV infection. In this review, LGE and HSV were reported in 8 and 6 out of 12 research, respectively, yet with lower prevalence.

Oral hairy leukoplakia (OHL), Kaposi's sarcoma, and necrotizing ulcerative gingivitis (NUG) are more common in adult than in children. However, these lesions can also be observed in children, as being identified in 5, 2, and 1 research, respectively. The presence of these lesions is pathognomonic of HIV infection and commonly indicates moderate or severe progression of the disease; therefore, an appropriate follow-up is essential [23].

It is the limitation of this study to determine the presence of oral manifestation based on ARV therapy and degree of immune suppression (CD4 cell count), as not all included studies presented complete demographic characteristics of the study population. Furthermore, all studies employed a one-time oral examination without subsequent follow-up assessment. Therefore, the criteria for children on ART and non-ART excluded the period of therapy, except a study of Baghirath et al., who recorded lower oral manifestations in children on long-term ART therapy ( $\geq 3$ years) compared 
to short-term treatment ( $<3$ years) [13]. Longitudinal studies with regular screenings for oral lesions need to be conducted in order to accurately assess the efficacy of ART in suppressing oral manifestations.

In general, the studies included in this review consistently revealed a lesser number of children on ART presenting with oral lesions, except for oral pigmentation, which becomes more prevalent. Further studies need to focus on comparing oral manifestations in HIV-positive children in developing and developed countries.

\section{Conclusions}

Studies on oral manifestation in HIV-positive children are very limited, despite an extremely high-rate of infection in developing countries. Candidiasis remains to be the most common opportunistic infection found in HIV-positive children.

\section{Conflict of interest}

The authors declare no conflict of interest with respect to the research, authorship, and/or publication of this article.

\section{References}

1. Huber MA, Redding SW, Sankar V, Woo SB. Infectious disease. In: Greenberg and Glick: Burket's Oral Medicine. $12^{\text {th }}$ ed. Hamilton: BC Decker Inc.; 2015, pp. 560-561.

2. Maartens G, Celum C, Lewin SR. HIV infection: epidemiology, pathogenesis, treatment, and prevention. Lancet 2014; 384: 258-271.

3. United Nations Programme on HIV/AIDS (UNAIDS). 2018. UNAIDS data 2018. Available at: www.unaids.org (Accessed: 15.07.2017).

4. Shao Y, Williamson C. The HIV-1 epidemic: low to middle income countries. Cold Spring Harb Perspect Med 2012; 2: a007187.

5. Rahmalia A, Wisaksana R, Meijerink H, et al. Women with HIV in Indonesia: are they bridging a concentrated epidemic to the wider community? BMC Res Notes 2015; 8: 757.

6. Tobin NH, Aldrovandi GM. Immunology of pediatric HIV infection. Immunol Rev 2013; 254: 143-169.

7. Becquet R, Marston M, Dabis F, et al. Children who acquire HIV infection perinatally are at higher risk of early death than those acquiring infection through breastmilk: a meta-analysis. PLoS One 201; 7: e28510.

8. Rwenyonyi CM, Kutesa A, Muwazi L, Okullo I, Kasangaki A, Kekitinwa A. Oral manifestations in HIV/AIDS-infected children. Eur J Dent 2011; 5: 291-298.

9. Ranganathan K, Geethalakshmi E, Krishna Mohan Rao U, Vidya KM, Kumarasamy N, Solomon S. Orofacial and systemic manifestations in 212 paediatric HIV patients from Chennai, South India. Int J Paediatr Dent 2010; 20: 276-282.

10. Davila ME, Gil M. Oral manifestations and dental caries in children exposed to human immunodeficiency virus. Rev Salud Publica 2011; 13: 833-843.

11. Ponnam SR, Srivastava G, Theruru K. Oral manifestations of human immunodeficiency virus in children: An institutional study at highly active antiretroviral therapy centre in India. J Oral Maxillofac Pathol 2012; 16: 195-202.

12. Adebola AR, Adeleke SI, Mukhtar M, Osunde OD, Akhiwu BI, Ladeinde A. Oral manifestation of HIV/AIDS infections in paediatric Nigerian patients. Niger Med J 2012; 53: 150-154.

13. Baghirath PV, Krishna AB, Gannepalli A. Oral manifestations of HIV in children receiving anti-retroviral therapy in Hyderabad, India. Eur Arch Paediatric Dent 2013; 14: 389-395.

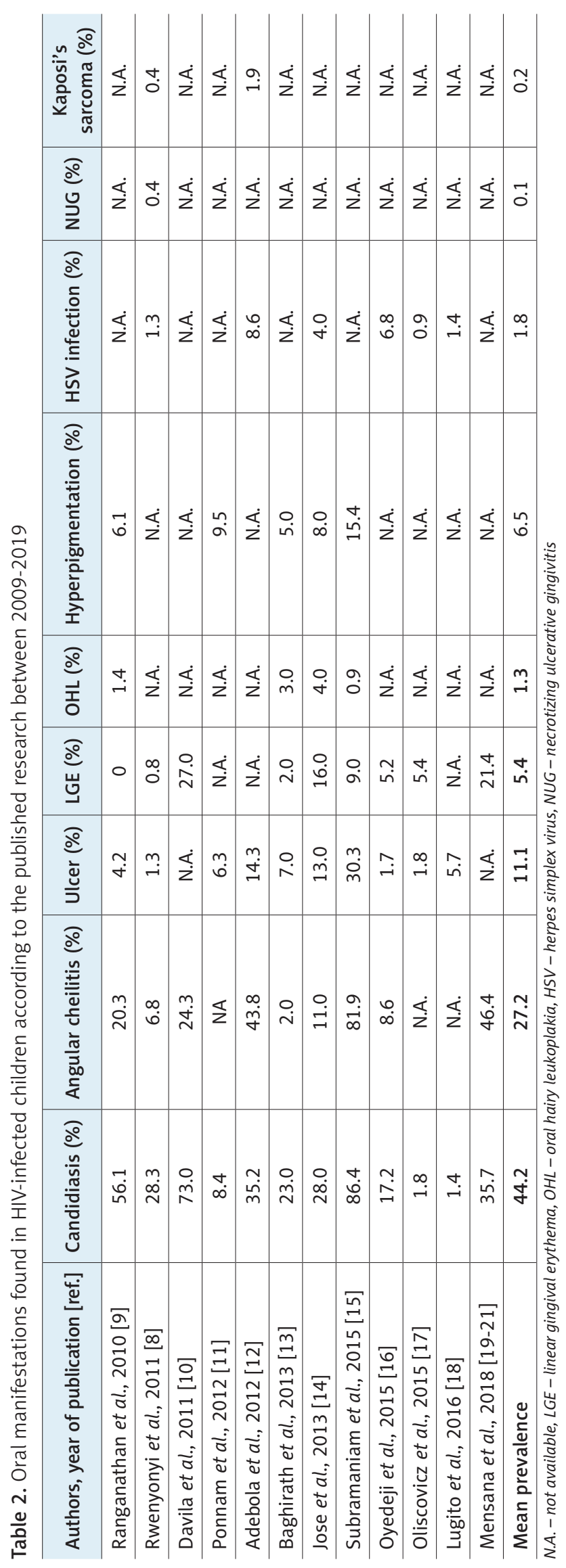


14. Jose R, Chandra S, Puttabuddi JH, et al. Prevalence of oral and systemic manifestations in pediatric HIV cohorts with and without drug therapy. Curr HIV Res 2013; 11: 498-505.

15. Subramaniam P, Kumar K. Oral mucosal lesions and immune status in HIV-infected Indian children. J Oral Pathol Med 2015; 44: 296-299.

16. Oyedeji OA, Gbolahan OO Abe EO, Agelebe E. Oral and dental lesions in HIV infected Nigerian children. Pan Afr Med J 2015; $20: 287$.

17. Oliscovicz NF, Pomarico L, Castro GF, Souza IP. Effect of highly active antiretroviral therapy use on oral manifestations in pediatric patients infected with HIV. Indian J Dent Res 2015; 26: 200-204.

18. Lugito M, Kurniati N, Sasanti H. Oral findings in children with human immunodeficiency virus treated with highly active antiretroviral therapy: an institutional study in Indonesia. JIDMR 2016; 2016: 306-311.

19. Mensana MP, Ernawati DS, Nugraha AP, et al. Oral candidiasis profile of the Indonesian HIV-infected pediatric patients at UPIPI Dr. Soetomo General Hospital, Surabaya, Indonesia. HIV AIDS Rev 2018; 17: 272-277.

20. Mensana MP, Nugraha AP, Ernawati DS, et al. Sensitivity and specificity of linear gingival erythema as immune suppression marker in pediatric HIV-infected at UPIPI Soetomo General Hospital Surabaya, Indonesia. IJPHRD 2019; 10: 572-577.

21. Mensana MP, Nugraha AP, Ernawati DS, Triyono EA, Husada D, Prasetyo RA. Correlation of oral hairy leukoplakia, HAART and CD4+ in HIV-infected pediatric patients at UPIPI Soetomo Hospital Surabaya, Indonesia. JIDMR 2019; 812: 165-169.

22. Pakfetrat A, Falaki F, Delavarian Z, Dalirsani Z, Sanatkhani M, Marani MZ. Oral manifestations of human immunodeficiency virusinfected patients. Iran J Otorhinolaryngol 2015; 27: 43-54

23. Leao JC, Ribeiro CM, Carvalho AAT, Frezzini C, Porter S. Oral complications of HIV disease. Clinics 2009; 64: 459-470.

24. Gondak RO, da Silva-Jorge R, Jorge J, Lopes MA, Vargas PA. Oral pigmented lesions: clinicopathologic features and review of the literature. Med Oral Patol Oral Cir Bucal 2012; 17: e919-e924.

25. Singh SK, Rai T. A case of zidovudine induced pigmentation on palms and soles. Indian Dermatol Online J 2014; 5: 98-99. 